\title{
Evaluating the impact of different early literacy interventions on low-income Costa Rican kindergarteners
}

\section{Citation}

Rolla San Francisco, Andrea, Melissa Arias, Renata Villers, and Catherine Snow. 2006.

"Evaluating the Impact of Different Early Literacy Interventions on Low-Income Costa Rican Kindergarteners." International Journal of Educational Research 45 (3) (January): 188-201. doi:10.1016/j.ijer.2006.11.002.

\section{Published Version}

doi:10.1016/j.ijer.2006.11.002

\section{Permanent link}

http://nrs.harvard.edu/urn-3:HUL.InstRepos:34785387

\section{Terms of Use}

This article was downloaded from Harvard University's DASH repository, and is made available under the terms and conditions applicable to Other Posted Material, as set forth at http:// nrs.harvard.edu/urn-3:HUL.InstRepos:dash.current.terms-of-use\#LAA

\section{Share Your Story}

The Harvard community has made this article openly available.

Please share how this access benefits you. Submit a story.

Accessibility 
Published in:

International Journal of Educational Research, December 2006.

(Published in: Rolla San Francisco, A., Arias, M., Villers, R., \& Snow, C. (2006).Evaluating the impact of different early literacy interventions on low-income Costa Rican kindergarteners. International Journal of Educational Research, 45.3: pp. 188-201.)

\title{
Evaluating the Impact of Different Early Literacy Interventions on Low-Income Costa Rican Kindergarteners
}

\author{
Andrea Rolla San Francisco* \\ Harvard University Graduate School of Education \\ Gertrudis Echeñique 215, No. 22 \\ Las Condes, Santiago, Chile \\ $011-56-2-2086457$ \\ arollasf@post.harvard.edu
}

Melissa Arias

Renata Villers

Association Amigos del Aprendizaje

San José, Costa Rica

Catherine Snow

* Corresponding author 
Harvard University Graduate School of Education 


\begin{abstract}
Grade retention has been the de facto policy for children with academic difficulties in many Latin American countries (Schiefelbein \& Wolff, 1992). In Costa Rica, $14.9 \%$ of public school children were retained in first grade in 2002. In a study of first grade classrooms in Costa Rica, children identified as in need of repeating first grade were found to have lower levels of reading ability (Rolla San Francisco, Arias, Villers, \& Snow, in press). There has been a greater focus in recent years on the importance of prevention of educational difficulties, versus repetition, as the most cost-effective and efficient way of providing educational opportunities to low-income children. There is little rigorous research evaluating the impact of different interventions on the early literacy skills of low-income children in developing countries as a way to prevent posterior academic difficulties.

This experimental study evaluated the differential impact of three early literacy interventions - tutoring, classroom activities, and work with families - on the emergent literacy skills of low-income Costa Rican kindergarteners. Tutoring or a combination of all three interventions were the most effective, while providing high-quality materials to teachers without training had no impact, but more intensive interventions of longer duration will probably be needed to ensure long-term impact on first grade repetition and eventual school dropout. Continuing research will assess the impact of these interventions on student outcomes and repetition rates in first grade, as well as exploring the impact of the more intensive intervention of professional development.
\end{abstract}

Keywords: Educational interventions, Evaluation, Emergent literacy skills 


\section{Introduction}

Research carried out in several countries suggests that children who begin first grade as poor readers are more likely to continue to struggle with reading - and therefore the rest of their academic subjects - throughout their academic careers (Clay, 1991; Cunningham \& Stanovich, 1997; Ferreiro \& Teberosky, 1982; Juel, 1988; Sanford, 2000). In addition, children from low-income families are disproportionately more likely to struggle with reading throughout their schooling (Snow, Burns, \& Griffin, 1998). High-quality literacy interventions have demonstrated that the incidence of reading difficulties in most beginning readers, including low-income children, can be reduced if the appropriate early experiences around language and literacy are provided (e.g., Vellutino \& Scanlon, 2002).

\section{Early Literacy Skills}

Some of the early literacy skills that have proven to be the most predictive of children's later reading ability in Spanish and other languages are letter identification, phonological awareness (the ability to manipulate the oral sounds in language), vocabulary, concepts about print, and early reading (Bravo, 1995; Bravo et al., 2001; Chan \& Siegel, 2001; Defior, 1996a, 1996b; González, 1996; Jiménez, 1996; McCardle et al., 2001; Siok \& Fletcher, 2001). 


\section{Early Literacy Interventions}

There has been a greater focus on the importance of prevention of educational difficulties in recent years as the most efficient way of providing educational opportunities to low-income children. This is true in the United States (Schweinhart, 1994), in developing countries (Myers, 1995), and more specifically in Latin America (Reimers, 1992). Research on emergent literacy suggests that reducing the number of children lacking literacy-related knowledge who enter first grade would reduce the number of children who would be retained in grade and/or need remedial instruction (Snow et al., 1998). Specifically, three kinds of early literacy interventions have proven successful: tutoring, phonological awareness, and family.

Tutoring interventions. Elbaum, Hughes, Moody, and Vaughn (2000) and Shanahan (1998), in two meta-analyses of over 100 studies of individual tutoring programs, found that, in general, students who received tutoring exhibited greater gains in reading than those who did not.

Phonological awareness interventions. In meta-analyses of over 50 studies on the role of phonemic awareness instruction in children's phonemic awareness and reading development, Blachman (2000) and Ehri et al. (2001) found that the effect size for phonological awareness outcomes was large and the effect on reading was moderate. Phonological awareness is the understanding that oral language is divided into words and sounds and the ability to manipulate those sounds.

Family interventions. Purcell-Gates (2000), in a review of the research on family literacy programs, suggests that children involved in some sort of family literacy program 
improve in skills important to academic success. One example of family literacy program that was shown to be successful in a quasi-experimental study was Project EASE (Early Access to Success in Education) (Jordan, Snow, \& Porche, 2000).

These three areas of research indicate promising results in the development of early literacy skills of children from low-income families. Relatively few studies have been done, however, comparing the impact of different kinds of early interventions on low-income kindergarten children's literacy outcomes (Barnett, 2002). Phonological awareness interventions with monolingual Spanish speakers have proven successful in improving young children's reading (Defior, 1996a; Defior \& Tudela, 1994; Domínguez, 1994, 1996a, 1996b), but little work has been done on the relative impact of family interventions or one-on-one tutoring.

\section{Costa Rica: The Educational Context}

There is growing concern in the Central American country of Costa Rica over secondary completion rates, which, for example, were reported to be $30 \%$ for adults aged 20-25 years in 1997 (Task Force on Education Equity and Economic Competitiveness in the Americas, 2001). Retention in grade, which is the most powerful predictor of later dropout (Randall \& Anderson, 1999), is also of concern. $14.9 \%$ percent of children repeated first grade in 2002 (Ministerio de Educación Pública, 2003).

The detrimental effects of retention in grade have been studied in the United States (Heubert \& Hauser, 1999; Jimerson, 1999; Holmes, 1989). The issue of retention in grade is particularly important in Latin American countries, where the default policy is often to allow children to repeat grades rather than to try to prevent their academic failure 
or provide them with intensive remedial interventions (Schiefelbein \& Wolff, 1992). Research in the United States indicates that students who have not learned how to read and write well in the early elementary grades are more likely to repeat grades and drop out of high school (Slavin, 1994). In a study of 16 public first grade classrooms in Costa Rica, children with reading difficulties were much more likely to be identified as future repeaters by their teachers at the end of the academic year (Rolla San Francisco et al., in press). One place to begin with Costa Rican children at risk for academic difficulties is to intervene early, developing their early literacy skills and preparing them for the task of learning to read in first grade.

Because there is no public provision for education for children younger than five in Costa Rica, the earliest logical point to intervene is kindergarten. In 2001, $82.7 \%$ of eligible children attended kindergarten (Proyecto Estado de la Nación, 2002). In a prior study, Rolla San Francisco et al. (2005) established that Costa Rican children show rather limited literacy knowledge at the end of kindergarten.

What remains open to debate, however, is whether early literacy interventions with low-income children that are based on research in other countries can be effective in Costa Rica and, if so, which kind of intervention is the most effective in improving the early literacy skills of kindergartners.

\section{Research Question}

The research study sought to answer the following question: 
Are early literacy interventions, namely tutoring, classroom activities, and work with families, effective in developing the early literacy skills of Costa Rican kindergartners attending schools in low-income neighborhoods?

\section{Methodology}

\section{$\underline{\text { Participants }}$}

The participants in this study were 210 low-income kindergarteners attending four public schools in San José, Costa Rica. The volunteer tutors participating in the study were public and private high school students.

\section{Tasks}

The kindergarten children were assessed on several early literacy measures.

Concepts about Print. Children's understandings of the functioning of print (ability to identify the title of a book, etc.) was assessed using the Spanish-language version of Clay’s Concepts about Print Test (Escamilla, Andrade, Basurto, \& Ruiz, 1996).

Letter Identification. Children's ability to identify the letters of the alphabet was evaluated using the Spanish-language adaptation of Clay's Letter Identification task (Escamilla et al., 1996). 
Phonological Awareness. Children's ability to manipulate oral language was tested by asking them to identify the initial sounds in words, separate a word into its requisite sounds, and blend the constituent sounds to make a word. These skills were tested using the Spanish Phonological Test (Wagner, Torgesen, \& Rashotte, No Date).

Vocabulary. Children's vocabulary was assessed using the Test de Vocabulario sobre Dibujos Woodcock (Woodcock, 1991).

Reading. To identify any children who begin reading before or during the intervention, the children took the Spanish version of the Woodcock Letter-Word Identification Subtest (Woodcock, 1991).

\section{$\underline{\text { Procedure }}$}

The children were tested individually by trained research assistants at the beginning and end of the Costa Rican academic year.

\section{Assignment to Treatment}

The children were assigned to one of six groups:

1. Classroom Intervention

2. Family Intervention 
3. Tutoring Intervention

4. Combination (A Combination of Classroom, Family, \& Tutoring)

5. Materials Only

6. No Intervention

All classroom teachers in the participating schools received access to the materials utilized in the interventions, with the exception of a third classroom from one school, which received no materials and no interventions (No. 6). One classroom from each of the four schools was randomly chosen to receive the classroom intervention, while the other classrooms did not receive the classroom intervention. For assignment to treatments within schools and classrooms, see Table 1. Because the classroom intervention was necessarily at the classroom level, completely random assignment of individuals to treatments was not possible. Within classrooms, children were grouped into homogeneous blocks based on their scores at the beginning of the year on the letter identification task (a proxy for incoming emergent literacy skills), and then children within each block were randomly assigned to a treatment condition. In the case of classrooms receiving the classroom intervention, children were assigned to classroom intervention (Intervention No. 1) or a combination of all three interventions (classroom, family, and tutoring, or Intervention No. 4). In the case of classrooms not receiving the classroom intervention, children were assigned to one of three possible groups: tutoring, family, or materials only (Interventions 2, 3, and 5, respectively).

[Table 1 to be inserted about here.] 


\section{The Interventions: Family}

The family intervention was a Spanish-language adaptation of Project EASE (Jordan et al., 2000). The intervention consisted of five sessions. Each parent education session was followed by an opportunity for parents and children to engage in structured, hands-on activities. Over the following three weeks, families were supposed to do structured activities around oral and written language at home with their children. The original Project EASE, implemented in the United States, had impact on vocabulary. Therefore, the hypothesis was that the intervention as implemented in Costa Rica would most probably have an impact on vocabulary.

\section{Tutoring Intervention}

The tutoring intervention consisted of a maximum of 21 tutoring sessions of about 45 minutes each. Tutors tutored either one or two children who were at approximately equivalent levels. Tutors completed three sets of activities with children per session: reading, writing, and work on letters and/or syllables. Tutors had access to children's books, each with a brief guide inside suggesting possible activities to do. Tutors were asked to fill out a $\log$ of activities they had done with their child or children. The hypothesis for the tutoring intervention was that it would have impact on letter identification and concepts about print, given the focus on reading stories to the children and the explicit teaching of letter-sound relationships. 


\section{Classroom Intervention}

The classroom intervention focused on the strengthening of phonological awareness and letter-sound relationships. The coordinator conducted 18 sessions of approximately 45 minutes with all children from each intervention classroom. The first two sessions focused on the concept of word, the next three on the concept of syllable (a salient unit in the Spanish language), and the final 13 focused on individual sounds or phonemes. The activities themselves were a combination of reading and reciting wellknown Costa Rican children's poetry and activities from different phonological awareness curricula (Calero Guisado, Pérez González, Maldonado Rico, \& Sebastián Gascón, 1997; Bear, Invernizzi, Templeton, \& Johnston, 2000; Adams, Foorman, Lundberg, \& Beeler, 1998; Blachman, Ball, Black, \& Tangel, 2000). The hypothesis for the phonological awareness intervention was that it would have an impact on phonological awareness and decoding.

\section{Analyses}

\section{$\underline{\text { Item Analysis }}$}

The results of the item analysis on the assessments indicated appropriate internal consistency (Rolla San Francisco et al., 2005). Cronbach's alpha ranged from .87 to .99 . 


\section{Data Analysis}

Descriptive statistics for the different interventions were examined (see Tables 2 \& 3). Because the results from the two groups (materials only and no intervention) were not significantly or substantively different, the two groups were merged to create one control group, as reflected in Table 2, and will be referred to as such from now on. Two girls were removed from the data set because they scored near ceiling at the beginning of the year. To simplify the interpretation of results, composites were created reflecting the major constructs of interest. A print composite was created using letter identification, concepts about print, and reading, while a language composite was created using vocabulary and phonological awareness. The descriptive statistics for the composites can be found in Table 4. There were no significant differences among groups on pretest scores or on maternal education, except that the children in tutoring had higher pretest scores on phonological awareness than children in the control group or a combination of all three interventions.

[Tables 2, 3, and 4 to be inserted about here.]

Repeated measures MANOVA was utilized to examine differences on the preand posttest assessments for children from different interventions. Group membership in the interventions was tested as a between-subjects factor and time was tested as a withinsubjects factor. Multiple regression analyses were conducted to detect a dosage effect for the interventions. For example, the number of tutoring sessions attended by each child was included as a predictor variable in order to assess the impact of the total number of tutoring sessions. 


\section{Answering the Research Question}

The results indicate that early literacy interventions based on international research were effective in developing some but not all early literacy skills of low-income Costa Rican kindergartners, particularly tutoring and the combination of all three interventions. Both tutoring and the combination of all three interventions had significant effects on concepts about print and on letter identification (see Table 5). Tutoring had been predicted to have an impact on letter identification and concepts about print; what was surprising was that neither of the other two interventions had an impact on the predicted outcomes and that the combination of outcomes only had an impact on the outcomes that were associated with tutoring. While all groups start out with similar results on the pretest, over time the children who received tutoring and those who received the combination of interventions finished the year with scores about 2 points higher than the other intervention groups (about 1 standard deviation higher) and 1 point higher than the control group (about .5 of a standard deviation).

[Table 5 to be inserted about here.]

Letter identification showed the greatest growth for the children receiving the combination of all three interventions; this group started off with the lowest predicted pretest mean and finished the year with the highest predicted posttest mean of 24 letters, versus 19 for tutoring (about .3 of a standard deviation difference), 15 for the control group and the classroom intervention (about .5 of a standard deviation difference), and 14 
for family (about .5 of a standard deviation difference). These results can be found in Table 5.

In general, these results suggest a positive impact of certain interventions on emergent literacy skills associated with print. In order to make the results more easily interpretable, the print and language composites were utilized in Repeated Measures MANOVA to explore the impact of these interventions, as can be seen in Table 5. There was an impact of group membership over time for the print composite. Tutoring and the combination of all three interventions had the greatest impact over time. While all groups started off with similar scores at pretest, the combination of all three interventions finished the year with a print composite score that was about half a standard deviation higher on that composite score than the other groups, excluding tutoring. There was no significant impact of group membership over time on the language composite.

Children's participation in the interventions was related to improvement in their outcomes at the end of the year. For every tutoring session a child attended, s/he is predicted to have scored .4 points higher on the print composite. This means that if a child attended all 21 sessions, s/he is predicted to have scored 7.8 points higher on the print composite than children who had not attended any tutoring sessions. This is the equivalent of approximately $3 / 4$ of a standard deviation by the end of the year, a substantial improvement. Results can be found in Table 6. This result suggests that the tutoring intervention was successful in having an impact on the predicted outcomes that it was associated with designed to affect: knowledge about print.

[Table 6 to be inserted about here.] 
Children did better on the language composite at the end of the year if they had participated actively in all three interventions, due to an interaction among participation in the different interventions. For example, a child who received an average score at the language pretest who participated in all three interventions is predicted to score approximately 23 points on the language posttest, while children who had not participated in any of the interventions would be predicted to score 19 points, about a standard deviation less. Results can be found in Table 7. These results suggest that in order to have an impact on the language composite outcomes, children had to participate actively in all three interventions.

[Table 7 to be inserted about here.] 


\section{Discussion}

The interventions had an impact on poor Costa Rican kindergartners' early literacy skills, while the mere provision of high-quality materials to teachers did not. Overall, tutoring and particularly the combination of all three interventions were able to impact growth in students' concepts about print and letter identification, reflecting the predicted impact on print knowledge of the tutoring intervention. Vocabulary, phonological awareness, and reading were not directly impacted. On summary composite measures, tutoring and the combination of all three interventions had an impact on print but not language outcomes. When attendance was taken into account, however, the combination of all three interventions proved to have a substantial impact on language outcomes and tutoring on print outcomes. These results suggest that, by and large, the tutoring and the combination of all three interventions were the most successful in improving student results, particularly in outcomes related to print skills. The combination of all three interventions may be worth the effort to ensure long-term impact in children, although future research would need to demonstrate that these interventions can go to scale and that the costs of scaling up are reasonable. It would also seem reasonable to continue interventions of longer duration, i.e. at least throughout first grade.

Anecdotal observations of the interventions suggest that the family-involvement and the classroom interventions were not intensive enough by themselves. In the case of the family intervention, it is worth noting that it is more difficult to measure impact on a domain like vocabulary. Jordan et al. (2000) noted similar findings in their implementation of Project Ease in the United States; they found impact on vocabulary in 
only one assessment out of two. In addition, the Costa Rican parents involved in the intervention noted that it was the first time anyone had indicated to them that they were their children's first teachers. The family intervention was first implemented in a US context where parents are more informed about the stimulation they should provide their children and engage in more early literacy activities at home (for a more detailed exploration of this comparison, see Rolla San Francisco et al., 2005). A qualitative study of children's family lives and family interactions around literacy is currently being conducted to examine potential cultural differences which may make the family intervention less effective in the Costa Rican context and how to improve it.

The pretest results on phonological awareness suggested that the children were beginning at a very low level, exhibiting near floor effects on phonemic segmentation. These floor effects were still present at the end of the year, indicating that these children probably needed a much more intensive intervention. Current research is currently evaluating the impact of a much more intensive phonological awareness intervention as well as varying the format of instruction (small versus whole group instruction).

On a methodological level, this study suggests that it is possible to adapt international research done mostly in developed countries to a developing country's context. Children improved on the appropriate emergent literacy skills, albeit not enough for long-term impact, perhaps. These low-income children enter with much lower early literacy skills than in other contexts and therefore need more intensive interventions. On a policy level, this study provides guidance in the allocation of resources in an early intervention program in literacy through its comparison of different interventions. It should be noted, however, that this study design does have potential clustering effects, 
which may skew the results. It should be noted that analyses comparing paternal educational levels with average levels in Costa Rica did indicate that the families in the sample were representative of the spread of the Costa Rican population overall.

\section{Conclusion}

The most important policy recommendation is the need to focus on the roots of the current challenges in education in Latin America: low levels of academic achievement, grade repetition, in particular in first grade, and eventual school dropout. One potential strategy to prevent these problems is the implementation of developmentally appropriate practice around early literacy skills at the preschool and early elementary level. The results of the interventions document that individual tutoring, along or in combination with other targeted programs, was effective in improving emergent literacy skills that are a barrier to learning to read in Costa Rica, and may be an effective intervention in other developing nations where weak early literacy skills impede learning to read. Providing teachers with high-quality materials had no impact on student outcomes. Improving student achievement should aid in reducing both repetition in first grade and eventual school dropout and improve the chances that low-income children will finish school and have access to more opportunities, both personally and professionally. 


\section{Bibliography}

Adams, M. J., Foorman, B. R., Lundberg, I., \& Beeler, T. (1998). Phonemic Awareness in Young Children: A Classroom Curriculum. Baltimore, MD: Paul H. Brookes.

Barnett, W. S. (2002). Preschool education for economically disadvantaged children: Effects on reading achievement and related outcomes. In S. B. Neuman \& D. K. Dickinson (Eds.), Handbook of Early Literacy Research. New York: Guilford.

Bear, D. R., Invernizzi, M., Templeton, S., \& Johnston, F. (2000). Words Their Way: Word Study for Phonics, Vocabulary, and Spelling Instruction. Upper Saddle River, NJ: Merrill.

Blachman, B. A. (2000). Phonological awareness. In M. L. Kamil, P. B. Mosenthal, P. D. Pearson \& R. Barr (Eds.), Handbook of Reading Research (Vol. III, pp. 483-502). Mahwah, NJ: Lawrence Erlbaum.

Blachman, B. A., Ball, E. W., Black, R., \& Tangel, D. M. (2000). Road to the Code: A Phonological Awareness Program for Young Children. Baltimore, MD: Paul H. Brookes. Bravo, L. (1995). A Four Year Follow-up Study of Low Socioeconomic Status, Latin American Children with Reading Difficulties. International Journal of Disability, Development \& Education 42(3), 189-202.

Bravo, L., Villalón, M., \& Orellana, E. (2001). Procesos predictivos del aprendizaje inicial de la lectura en primer año básico. Boletín de investigación educacional, Facultad de educación, Pontificia Universidad Católica de Chile 16, 149-160.

Calero Guisado, A., Pérez González, R., Maldonado Rico, A., \& Sebastián Gascón, M. E. (1997). Materiales Curriculares para Favorecer el Acceso a la Lectura en Educación Infantil. Madrid: Editorial Escuela Española.

Chan, C. K. K., \& Siegel, L. S. (2001). Phonological Processing in Reading Chinese among Normally Achieving and Poor Readers. Journal of Experimental Child Psychology 80(1), 23-43.

Clay, M. M. (1991). Becoming Literate: The Construction of Inner Control. Portsmouth, NH: Heinemann.

Cunningham, A., \& Stanovich, K. E. (1997). Early reading acquisition and its relation to reading experience and ability 10 years later. Developmental Psychology, 33(6), 934-945. 
Defior, S. (1996a). La conciencia fonológica y la adquisición de la lectoescritura. Infancia y Aprendizaje 67-68, 91-113.

Defior, S. (1996b). Una clasificación de las tareas utilizadas en la evaluación de las habilidades fonológicas y algunas ideas para su mejora. Infancia y Aprendizaje 73, 49-63. Defior, S., \& Tudela, P. (1994). Effect of phonological training on reading and writing acquisition. Reading and Writing: An Interdisciplinary Journal 6, 299-320.

Domínguez, A. B. (1994). Importancia de las habilidades de análisis fonológico en el aprendizaje de la lectura y de la escritura. Estudios de Psicología 51, 59-70.

Domínguez, A. B. (1996a). El desarrollo de habilidades de análisis fonológico a través de programas de enseñanza. Infancia y Aprendizaje 76, 69-81.

Domínguez, A. B. (1996b). Evaluación de los efectos a largo plazo de la enseñanza de habilidades de análisis fonológico en el aprendizaje de la lectura y la escritura. Infancia y Aprendizaje 76, 83-96.

Ehri, L. C., Nunes, S. R., Willows, D. M., Valeska Schuster, B., Yaghoub-Zadeh, Z., \& Shanahan, T. (2001). Phonemic awareness instruction helps children learn to read: Evidence from the National Reading Panel's meta-analysis. Reading Research Quarterly $36(3), 250-287$.

Elbaum, B., Hughes, M. T., Moody, S. W., \& Vaughn, S. (2000). How effective are oneto-one tutoring programs in reading for elementary students at risk for reading failure? A meta-analysis of the intervention research. Journal of Educational Psychology 92(4), 605-619.

Escamilla, K., Andrade, A. M., Basurto, A. G. M., \& Ruiz, O. A. (1996). Spanish Reconstruction of An Observation Survey, a Bilingual Text: Instrumento de Observación de los Logros de Lecto-escritura Inicial. Portsmouth, NH: Heinemann.

Ferreiro, E., \& Teberosky, A. (1982). Literacy Before Schooling (K. G. Castro, Trans.). Exeter, NH: Heinemann.

González, M. J. (1996). Aprendizaje de la lectura y conocimiento fonológico: Análisis evolutivo e implicaciones educativas. Infancia y Aprendizaje 76, 97-107.

Heubert, J.P. \& Hauser, R.M., Eds. (1999). Promotion and retention. In High Stakes: Testing for Tracking Promotion and Graduation. Washington, DC: National Academy Press. pp. 114-161. 
Holmes, C.T. (1989). Grade level retention effects: A meta-analysis of research studies. In L.A. Shepard \& M.L. Smith (Eds.), Flunking Grades: Research and Policies on Retention. London: Falmer.

Jiménez, J. E. (1996). Conciencia fonológica y retraso lector en una ortografía transparente. Infancia y Aprendizaje 76, 109-121.

Jimerson, R. (1999). On the Failure of Failure: Examining the Association Between Early Grade Retention and Education and Employment Outcomes During Late Adolescence. Journal of School Psychology 37(3), 243-272.

Jordan, G. E., Snow, C. E., \& Porche, M. V. (2000). Project EASE: The effect of a family literacy project on kindergarten students' early literacy skills. Reading Research Quarterly 35(4), 524-546.

Juel, C. (1988). Learning to read and write: a longitudinal study of 54 children from first through fourth grades. Journal of Educational Psychology 80(4), 437-447.

McCardle, P., Scarborough, H. S., \& Catts, H. W. (2001). Predicting, explaining, and preventing children's reading difficulties. Learning Disabilities Research \& Practice 16(4), 230-239.

Ministerio de Educación Pública. (2003). Repitentes en I y II Ciclos, según año cursado. Retrieved Feb. 11, 2003.

Myers, R. (1995). The twelve who survive: Strengthening programmes of early childhood development in the Third World. Ypsilanti, MI: High/Scope.

Proyecto Estado de la Nación. (2002). Estado de la Nación en Desarrollo Humano Sostenible: Un Análisis Amplio y Objetivo sobre la Costa Rica que Tenemos a Partir de los Indicadores Más Actuales. Pavas, Costa Rica: Proyecto Estado de la Nación.

Purcell-Gates, V. (2000). Family Literacy. In M. L. Kamil, P. B. Mosenthal, P. D. Pearson \& R. Barr (Eds.), Handbook of Reading Research (Vol. III, pp. 853-870). Mahwah, NJ: Lawrence Erlbaum.

Randall, L., \& Anderson, J. B. (Eds.). (1999). Schooling for Success: Preventing Repetition and Dropout in Latin American Primary Schools. Armonk, NY: M.E. Sharpe. Reimers, F. (1992). Towards a Policy for Early Childhood Education in Latin America and the Caribbean. Washington, DC: Agency for International Development. 
Rolla San Francisco, A., Arias, M., \& Villers, R. (2005). Quality Early Childhood Education in Costa Rica? Policy, Practice, Outcomes, and Challenges. Early Years: An International Journal of Research and Development 25, 113-127.

Rolla San Francisco, A., Arias, M., Villers, R., \& Snow, C. (in press). The Importance of Reading Skills, Prereading Skills, and Family in Teachers' Decisions To Retain Children: A Case Study in Costa Rica. Aula Abierta.

Sanford, E. (2000). A Spanish Version of The Lexile Framework for Reading. Popular Measurement 3(1), 25-26.

Schiefelbein, E., \& Wolff, L. (1992). Repetition and Inadequate Achievement in Latin America's Primary Schools: A Review of Magnitudes, Causes, Relationships, and Strategies. Washington, DC: World Bank.

Schweinhart, L. J. (1994). Lasting Benefits of Preschool Programs. ERIC Digest (No. ED365478). Urbana, IL: ERIC Clearinghouse on Elementary and Early Childhood Education.

Shanahan, T. (1998). On the effectiveness and limitations of tutoring in reading. Review of Research in Education 23, 217-234.

Siok, W. T., \& Fletcher, P. (2001). The Role of Phonological Awareness and VisualOrthographic Skills in Chinese Reading. Developmental Psychology 37(6), 886-899.

Slavin, R. E. (1994). Preventing Early School Failure: Research, Policy, and Practice.

Snow, C. E., Burns, M. S., \& Griffin, P. (1998). Preventing reading difficulties in young children. Washington, DC: National Academy Press.

Task Force on Education Equity and Economic Competitiveness in the Americas. (2001, November). Lagging Behind: A Report Card on Education in Latin America, Washington, D.C.

Vellutino, F.R., \& Scanlon, D.M. (2002). The Interactive Strategies Approach to Reading Intervention. Contemporary Educational Psychology 27, 573-635.

Wagner, R. K., Torgesen, J. K., \& Rashotte, C. (No Date). Spanish Phonological Test. Austin, TX: Pro-Ed.

Woodcock, R. W. (1991). Woodcock Language Proficiency Battery, Revised. Itasca, IL: Riverside. 
Table 1. Assignment to treatment.

\begin{tabular}{|c|c|c|c|c|}
\hline & & \multicolumn{3}{|c|}{ Treatment } \\
\hline \multirow[t]{3}{*}{ School 1} & Classroom 1 & \multicolumn{2}{|l|}{ Classroom } & Combination* \\
\hline & Classroom 2 & Family & Tutorin & Materials Only** \\
\hline & Classroom 3 & \multicolumn{3}{|c|}{ No Intervention } \\
\hline \multirow[t]{2}{*}{ School 2} & Classroom 4 & \multicolumn{2}{|l|}{ Classroom } & Combination* \\
\hline & Classroom 5 & Family & Tutorin & Materials Only** \\
\hline \multirow[t]{2}{*}{ School 3} & Classroom 6 & \multicolumn{2}{|l|}{ Classroom } & Combination* \\
\hline & Classroom 7 & Family & Tutorin & Materials Only** \\
\hline \multirow[t]{2}{*}{ School 4} & Classroom 8 & \multicolumn{2}{|l|}{ Classroom } & Combination* \\
\hline & Classroom 9 & Family & Tutorin & Materials Only** \\
\hline
\end{tabular}

* Combination signifies that the child received all three treatments: classroom, family, and tutoring.

** Materials only means that the children's teachers had access to the same materials that were used in the interventions. 
Table 2. Descriptive Statistics on pre- and post-test outcomes by intervention.

$$
\begin{aligned}
& \text { Control Classroom Family Tutoring Combination Total } \\
& \text { Group }
\end{aligned}
$$

\begin{tabular}{|c|c|c|c|c|c|c|c|}
\hline & & $\mathrm{n}=55$ & $\mathrm{n}=41$ & $\mathrm{n}=30$ & $\mathrm{n}=32$ & $\mathrm{n}=50$ & $\mathrm{n}=208$ \\
\hline Concepts about print & Mean & 2.0 & 2.2 & 1.4 & 1.8 & 1.8 & 1.8 \\
\hline Pretest & $\mathrm{SD}$ & 2.4 & 2.5 & 1.9 & 2.1 & 2.2 & 2.3 \\
\hline Concepts about print & Mean & 4.8 & 3.8 & 3.7 & 5.9 & 5.8 & 4.9 \\
\hline Posttest & SD & 2.9 & 3.3 & 2.9 & 3.4 & 3.1 & 3.2 \\
\hline Letter identification & Mean & 5.7 & 4.8 & 5.5 & 4.6 & 4.1 & 4.9 \\
\hline Pretest & $\mathrm{SD}$ & 10.3 & 8.9 & 11.6 & 9.6 & 6.6 & 9.3 \\
\hline Letter identification & Mean & 15.4 & 14.7 & 14.4 & 19.3 & 23.9 & 17.8 \\
\hline Posttest & $\mathrm{SD}$ & 19.9 & 15.8 & 16.6 & 19.9 & 18.8 & 18.7 \\
\hline \multirow[t]{2}{*}{ Vocabulary Pretest } & Mean & 20.9 & 20.0 & 20.3 & 20.5 & 19.8 & 20.3 \\
\hline & $\mathrm{SD}$ & 2.8 & 2.4 & 2.9 & 2.8 & 3.5 & 2.9 \\
\hline \multirow[t]{2}{*}{ Vocabulary Posttest } & Mean & 21.8 & 21.3 & 21.5 & 22.3 & 21.5 & 21.7 \\
\hline & SD & 4.1 & 3.6 & 2.5 & 2.8 & 2.9 & 3.3 \\
\hline \multirow[t]{2}{*}{ Reading Pretest } & Mean & 4.6 & 4.3 & 4.5 & 6.1 & 4.4 & 4.7 \\
\hline & SD & 2.0 & 2.1 & 1.7 & 9.0 & 1.5 & 3.9 \\
\hline \multirow[t]{2}{*}{ Reading Posttest } & Mean & 6.4 & 7.2 & 7.3 & 9.0 & 8.4 & 7.6 \\
\hline & $\mathrm{SD}$ & 3.8 & 6.9 & 8.3 & 10.3 & 5.7 & 6.9 \\
\hline Phonological Awareness & Mean & 4.3 & 5.3 & 4.5 & 6.7 & 4.2 & 4.9 \\
\hline Pretest & $\mathrm{SD}$ & 2.8 & 3.3 & 2.8 & 4.2 & 3.0 & 3.3 \\
\hline Phonological Awareness & Mean & 7.6 & 7.4 & 6.3 & 7.9 & 7.7 & 7.4 \\
\hline \multirow[t]{2}{*}{ Posttest } & $\mathrm{SD}$ & 4.2 & 8.2 & 4.1 & 3.8 & 5.9 & 5.5 \\
\hline & & $\mathrm{n}=52$ & $\mathrm{n}=36$ & $\mathrm{n}=26$ & $\mathrm{n}=30$ & $\mathrm{n}=41$ & $\mathrm{n}=185$ \\
\hline \multirow[t]{3}{*}{ Maternal Education } & Mean & 7.9 & 6.8 & 8.4 & 7.2 & 7.8 & 7.6 \\
\hline & SD & 3.1 & 2.6 & 2.9 & 2.6 & 3.6 & 3.0 \\
\hline & & $\mathrm{n}=43$ & $\mathrm{n}=29$ & $\mathrm{n}=21$ & $\mathrm{n}=27$ & $\mathrm{n}=37$ & $\mathrm{n}=157$ \\
\hline \multirow[t]{2}{*}{ Paternal Education } & Mean & 7.9 & 7.7 & 8.1 & 8.1 & 7.3 & 7.8 \\
\hline & $\mathrm{SD}$ & 3.0 & 2.4 & 3.5 & 2.9 & 3.3 & 3.0 \\
\hline
\end{tabular}


Table 3. Means and standard deviations of levels of participation in different interventions.

\begin{tabular}{|c|c|c|c|c|c|c|}
\hline & & $\begin{array}{l}\text { Control } \\
\text { Group }\end{array}$ & Classroom & Family & Tutoring & Combination \\
\hline \multirow[t]{2}{*}{ No. of tutoring sessions } & Mean & .0 & .0 & .0 & 13.8 & 14.4 \\
\hline & SD & .0 & .0 & .0 & 5.4 & 5.6 \\
\hline \multirow[t]{2}{*}{ No. of family sessions } & Mean & .0 & .0 & 3.5 & .0 & 3.5 \\
\hline & SD & .0 & .0 & 1.6 & .0 & 1.7 \\
\hline \multirow{2}{*}{$\begin{array}{l}\text { No. of family evaluations } \\
\text { filled out }\end{array}$} & Mean & .0 & .0 & 5.5 & .0 & 5.3 \\
\hline & SD & .0 & .0 & 3.4 & .0 & 4.2 \\
\hline \multirow[t]{2}{*}{ Classroom sessions attended } & Mean & .0 & 15.4 & .0 & .0 & 15.6 \\
\hline & SD & .0 & 2.0 & .0 & .0 & 2.7 \\
\hline
\end{tabular}


Table 4. Means and standard deviations of pre- and posttest composites by intervention.

$\begin{array}{llllllll} & & \begin{array}{l}\text { Control } \\ \text { Group }\end{array} & \text { Classroom } & \text { Family } & \text { Tutoring } & \text { Combination } & \text { Total } \\ & \text { Mean } & 5.1 & 4.7 & 4.8 & 5.2 & 4.3 & 4.8 \\ & \text { SD } & 5.3 & 4.9 & 5.9 & 8.2 & 3.5 & 5.5 \\ \text { Print composite pretest } & \text { Mean } & 11.2 & 10.8 & 10.7 & 14.3 & 16.1 & 12.7 \\ & \text { SD } & 10.2 & 9.5 & 10.3 & 12.9 & 10.7 & 10.8 \\ \text { Print composite posttest } & \text { Mean } & 15.0 & 15.0 & 14.8 & 16.1 & 14.3 & 15.0 \\ \text { Language pretest } & \text { SD } & 2.8 & 2.7 & 2.3 & 3.2 & 3.0 & 2.9 \\ \text { composite score } & & & & & & & \\ & \text { Mean } & 17.5 & 17.1 & 16.6 & 18.0 & 17.4 & 17.3 \\ \begin{array}{l}\text { Language composite } \\ \text { posttest }\end{array} & \text { SD } & 4.2 & 5.8 & 3.2 & 3.3 & 4.6 & 4.4\end{array}$


Table 5. Repeated Measures ANOVA Results.

\begin{tabular}{|c|c|c|c|c|}
\hline Source & Df & SS & MS & $\mathrm{F}$ \\
\hline \multicolumn{5}{|l|}{$\begin{array}{l}\text { Concepts about } \\
\text { print between } \\
\text { subjects }\end{array}$} \\
\hline Group & 4 & 86.54 & 21.64 & $2.62 *$ \\
\hline Error 1 & 203 & 1675.22 & 8.25 & \\
\hline \multicolumn{5}{|l|}{$\begin{array}{l}\text { Concepts about } \\
\text { print within } \\
\text { subjects }\end{array}$} \\
\hline Time & 1 & 881.23 & 881.23 & $134.99 * * *$ \\
\hline Group x Time & 4 & 97.75 & 24.44 & $3.74 * *$ \\
\hline Error 2 & 203 & 1325.22 & 6.53 & \\
\hline \multicolumn{5}{|c|}{$\begin{array}{l}\text { Letter } \\
\text { identification } \\
\text { between subjects }\end{array}$} \\
\hline Group & 4 & 1113.02 & 278.26 & .91 \\
\hline Error 1 & 203 & 62406.32 & 307.42 & \\
\hline \multicolumn{5}{|l|}{$\begin{array}{l}\text { Letter } \\
\text { identification } \\
\text { within subjects }\end{array}$} \\
\hline Time & 1 & 15614.27 & 15614.27 & $130.13 * * *$ \\
\hline Group x Time & 4 & 1946.00 & 486.50 & $4.05 * *$ \\
\hline Error 2 & 203 & 24358.88 & 119.99 & \\
\hline \multicolumn{5}{|c|}{$\begin{array}{l}\text { Vocabulary } \\
\text { between subjects }\end{array}$} \\
\hline Group & 4 & 46.69 & 11.67 & .79 \\
\hline Error 1 & 203 & 3003.70 & 14.80 & \\
\hline \multicolumn{5}{|l|}{$\begin{array}{l}\text { Vocabulary } \\
\text { within subjects }\end{array}$} \\
\hline Time & 1 & 197.81 & 197.81 & $42.07 * * *$ \\
\hline Group x Time & 4 & 13.19 & 3.30 & .70 \\
\hline Error 1 & 203 & 954.54 & 4.70 & \\
\hline \multicolumn{5}{|c|}{$\begin{array}{l}\text { Reading between } \\
\text { subjects }\end{array}$} \\
\hline Group & 4 & 194.10 & 48.53 & 1.02 \\
\hline Error 1 & 203 & 9652.05 & 47.55 & \\
\hline \multicolumn{5}{|l|}{$\begin{array}{l}\text { Reading within } \\
\text { subjects }\end{array}$} \\
\hline Time & 1 & 804.61 & 804.61 & $54.79 * * *$ \\
\hline Group x Time & 4 & 62.57 & 15.64 & 1.07 \\
\hline Error 2 & 203 & 2980.97 & 14.69 & \\
\hline
\end{tabular}


Table 5. Repeated Measures ANOVA Results (continued).

Source Df

SS

MS

F

Phonological

awareness

between subjects

Group 4

Error $1 \quad 203$

126.75

4343.01

31.69

21.39

Phonological

awareness within

subjects

Time

Group x Time 4

Error 2

203

559.05

79.15

3965.23

559.05

19.79

19.53

Print composite

between subjects

Group

School

Error 1

Print composite

within subjects

Time

Group x Time

School x Time

Error 2

4
3

3

200

621.73

636.65

155.43

217.88

104.38

5384.7

684.05

135.52

7365.55

5384.74

171.01

45.17

36.83

Language

composite

between subjects

Group

4

School

Error 1

3

200

Language

composite within

subjects

Time

Group x Time

School x Time

Error 2

\section{1}

4

3
170

$* \mathrm{p}<.05 * * \mathrm{p}<.01 * * * \mathrm{p}<.001$
75.70

83.41

3668.45

549.37

22.22

75.19

1688.40
18.93

27.80

18.34

549.37

5.55

25.06

9.93
1.48

2.08

$146.21 * * *$

$4.64 * *$

1.23

$28.62 * * *$

1.01

1.03

1.52

$63.16^{* * * *}$

.64

2.88* 
Table 6. Regression Analysis Dosage Effect for Print composite.

\begin{tabular}{lll} 
Predictor & $\begin{array}{l}\text { Model 1: } \\
\text { Baseline Model }\end{array}$ & $\begin{array}{l}\text { Model 2: } \\
\text { Intervention } \\
\text { Participation } \\
\text { variables }\end{array}$ \\
\hline Intercept & $7.82^{* * *}$ & $5.63 * * *$ \\
Print composite pretest & $1.13^{* * *}$ & $1.14 * * *$ \\
School 2 & -2.04 & $-3.65^{*}$ \\
School 3 & -.49 & -2.36 \\
School 4 & .29 & -1.45 \\
Scripted at-home book & & .31 \\
activities & & .09 \\
Classroom sessions & & $.37 * * *$ \\
Tutoring sessions & & .44 \\
R-square statistic & .33 & 200 \\
Error df & 203 & \\
$*$ p & & \\
& &
\end{tabular}


Table 7. Regression Analysis Dosage Effect for Language composite.

\begin{tabular}{|c|c|c|c|}
\hline Predictor & $\begin{array}{l}\text { Model 1: } \\
\text { Baseline Model }\end{array}$ & $\begin{array}{l}\text { Model 2: } \\
\text { Intervention } \\
\text { participation variables }\end{array}$ & $\begin{array}{l}\text { Model 3: Three-way } \\
\text { intervention } \\
\text { interaction }\end{array}$ \\
\hline Intercept & $8.47 * * *$ & $8.03 * * *$ & $8.23 * * *$ \\
\hline $\begin{array}{l}\text { Language composite } \\
\text { pretest }\end{array}$ & $.59 * * *$ & $.59 * * *$ & $.61 * * *$ \\
\hline $\begin{array}{l}\text { Scripted at-home book } \\
\text { activities }\end{array}$ & & .05 & -.12 \\
\hline Classroom sessions & & .008 & -.03 \\
\hline Tutoring sessions & & .05 & -.003 \\
\hline $\begin{array}{l}\text { Three-way intervention } \\
\text { interaction }\end{array}$ & & & $.001 *$ \\
\hline R-square statistic & .15 & .16 & .18 \\
\hline Error df & 206 & 203 & 202 \\
\hline
\end{tabular}

